\title{
School's Head Strategy in Improving for Services Participants of Training Skills in Education and Scientific Training Center Malahayati Aceh Indonesia
}

\author{
Fazri Hermanto \\ BP2IP Instructor Malahayati Aceh \\ Aceh Besar, Indonesia \\ profcut@unsyiah.ac.id
}

\author{
Cut Zahri Harun \\ Department of Educational Administration \\ Syiah Kuala University, Indonesia \\ profcut@unsyiah.ac.id
}

\author{
Sakdiah Ibrahim \\ Department of Educational Administration \\ Syiah Kuala University, Indonesia \\ profcut@unsyiah.ac.id
}

\begin{abstract}
The purpose of this study was to determine: the program formulation, execution management, and constraints faced by the head of the hall in the running manaje men and improve the professional instructor. This study uses descriptive method with a qualitative approach. Data collection techniques: Observation, Interviews and Study of Documentation studies. The subjects of this research was the head of the hall, sub-department heads, instructors, participants training. The results showed that: (1) The head of the hall in improving services to participants Diklat, formulation mechanism begins with finding out the cultural and social background, and consultation between stakeholders, instructor. Programs compiled, long-term, medium program and short-term programs, and all these programs focus on regulations Ministry Transportation as well as instructions from IMO ( International Maritime Organization ). All of this is already in the hall chief management contained in the program hall to improve the service. (2) The head of the hall carrying out management of head hall to improve pelayana $n$ by way of head hall management implement it to yourself as an example for his subordinates and the head of the hall make approaches unt uk improving professional instructors.
\end{abstract}

Keywords: management, leadership, professional instructor

\section{INTRODUCTION}

The success of a service in achieving its goals is highly dependent on its consumers, in the sense that the company provides quality services to its customers will be successful in achieving its goals. Now the quality of service has become a major concern in winning the competition. Service quality can be used as one of the institution's strategies to create customer satisfaction. A quality education depends on the goals and what will be done in education.

The definition of quality education must recognize that any education is included in a system. Quality in some parts of the system may be good, but poor quality exists in other parts of the system, which results in reduced quality of education as a whole from education. Service quality is known by comparing the expectations / interests of customers for ideal services with the services they actually receive.

Makawimbang (2013) Leaders are required to be able to encourage enthusiasm, use the values, beliefs and needs of subordinates to complete tasks and be able to do in situational very fast changing or crisisfilled situations, in other words able to display or create charismatic, full leadership inspiration, intellectual stimulation and the feeling that each subordinate is taken into account. Satori et. al (2013) Leaders who understand and want to realize their vision have a high awareness to be in a patient heart (which is based on noble abilities / skills and morality).

One of the efforts used to realize a complete human being is education. Therefore, National Education based on Pancasila aims to increase devotion to God Almighty, intelligence, skills, enhance character, strengthen personality, strengthen national spirit, and love the homeland, so as to foster development people who can build themselves and jointly responsible for nation building. The purpose of this research is to find out: program formulation, management implementation, and obstacles faced by the head of the hall in carrying out management and enhancing instructor professionalism. The purpose of this research is to find out: program formulation, management implementation, and obstacles faced by the head of the hall in carrying out management and enhancing instructor professionalism.

\section{METHODS}

This study uses descriptive method using a qualitative approach that describes, Sugiyono (2015) said qualitative research is a process of exploring and understanding the meaning of individual and group behavior, describing social problems or humanitarian problems. In the data collection technique contains the procedural sequence of the use of research tools. The research path contains steps that are carried out in broad outline from the management of research permits to the preparation of the results of the research report.

Data and information that has been obtained by the next researcher, analyzed and interpreted from the beginning of the study to the end. research by referring to the theoretical basis relating to the problem under study. Data analysis in qualitative research is done by classifying, directing, disposing of unnecessary, and organizing data (reducing data), summarizing the main things (data display) and drawing conclusions (data verification). 
III. RESULTS AND DISCUSSION Program of BP2IP's Principle to Improve Service to Participants Training in BP2IP Malahayati Aceh

Results showed that the program head of the hall to improve the professional competence of the instructor arranged at the beginning of each school year by a development schools team is including the annual program and semester's program and not well documented and neat. The planned program is to conduct guidance to the instructor regularly. Planning is preparation prepared by using all reasoning abilities for an action to be taken to achieve the goal. Planning which is an essential process of nature management of educational institutions.

Usman (2012) suggests that planning is a number of activities that are predetermined to be carried out in a certain period in order to achieve the stated goals. Planning includes things that are broad, complex, and require a lot of time. The core of planning is the formulation of goals and coordination of ways to achieve these goals. Planning has two very important meanings. The first is the beginning of the entire management process. Second, it functions to direct all activities in the organization.

Implementing The Principle in Improving Services for Training and Education Participants in BP2IP Malahayati Aceh

Based on the results of the study it can be concluded that the implementation of management / programs to improve instructors' professional competence begins with giving directions at the beginning of each semester. In carrying out school activities, the head of the hall seeks to create safe and comfortable school habits and situations. The development of school habits is directed at measurable targets to facilitate the achievement of teacher professional competence improvement. Head of the hall as a top manager at the school has a very strategic management at all in creating instructor, a professional asinstructorsprofessionalin desperate need of a leader and professional leadership of the hall as well.

Karwati \& Pariansa (2013) there are four roles of school principals as supervisors towards the creation of teacher professionalism are: (1) creating a conducive institutional climate in which the principal must be able to get closer and more open between teachers and principals, feeling safe and comfortable, creating an environment conducive learning, and optimizing teacher welfare; (2) providing opportunities and opportunities for optimizing the potential of teachers to provide opportunities and opportunities for increasing teacher potential; in this case the principal as the top manager must involve the teacher, without pressure; the principal will provide opportunities for teachers who create and innovate so that the teacher can optimize his abilities; (3) optimizing the management of the principal's leadership management is very influential on the professional process of teachers, where here the principal is as a conductor, motivator and coordinator; and (4) the implementation of clinical supervision as well as the objectives of the clinical supervision itself is to improve the basic skills of teachers related to their teaching competencies.

\section{CONCLUSION}

The head hall program to improve the ability of seafarers to learners has been well and efficiently prepared, be it the program for students, educators, and employees in the BP2IP Malahayati Aceh environment. The planned program is to approach all parties especially to students, because they are customers, the program enhances seafarers' abilities towards educators and students through trainings such as training, stimulation and so on, the program provides convenient facilities, and forms new programs namely improve the ability to speak English to students.

The management implementation to improve the service for the participants in the training of seafarers' ability to the students begins with giving a briefing at the beginning of the semester. In carrying out school activities, the school hall takes a family approach, and sanctions. The activities carried out have not yet been fully equipped and certainly cannot be used as expected.

\section{REFERENCES}

[1] Makawimbang, J. H. 2013. Quality Education Leadership. Bandung: Alfabeta.

[2] Karwati, G., and Priansa, H. 2013. Performance and Professionalism of Principals Building Quality Schools. Bandung: Alfabeta.

[3] Satori, D. M., Danny, A., and Komariah. 2013. Model of School Management Capacity Building (School Capacity Building) to Improve the Quality of Education. Journal of Educational Administration, XVII(1), 1-9.

[4] Sugiyono. 2015. Understanding Qualitative Research. Bandung: Alfabeta.

[5] Usman, N. 2012. Management of Performance Improvement in Quality of Citapustaka Teachers Media Pioneer. 